Prepared for the U.S. Department of Energy

under Contract DE-AC05-76RL01830

\title{
25 Year Lifetime for Flexible Buildings Integrated Photovoltaics
}

\author{
Mark E. Gross
}

July 2010

\section{Pacific Northwest}

NATIONAL LABORATORY

Proudly Operated by Battelle Since 1965 


\title{
DISCLAIMER
}

This report was prepared as an account of work sponsored by an agency of the United States Government. Neither the United States Government nor any agency thereof, nor Battelle Memorial Institute, nor any of their employees, makes any warranty, express or implied, or assumes any legal liability or responsibility for the accuracy, completeness, or usefulness of any information, apparatus, product, or process disclosed, or represents that its use would not infringe privately owned rights. Reference herein to any specific commercial product, process, or service by trade name, trademark, manufacturer, or otherwise does not necessarily constitute or imply its endorsement, recommendation, or favoring by the United States Government or any agency thereof, or Battelle Memorial Institute. The views and opinions of authors expressed herein do not necessarily state or reflect those of the United States Government or any agency thereof.

\author{
PACIFIC NORTHWEST NATIONAL LABORATORY \\ operated by \\ BATTELLE \\ for the \\ UNITED STATES DEPARTMENT OF ENERGY \\ under Contract DE-AC05-76RL01830
}

Printed in the United States of America
Available to DOE and DOE contractors from the Office of Scientific and Technical Information,
P.O. Box 62, Oak Ridge, TN 37831-0062;
ph: (865) 576-8401
fax: $(865)$ 576-5728
email: reports@adonis.osti.gov

\begin{abstract}
Available to the public from the National Technical Information Service, U.S. Department of Commerce, 5285 Port Royal Rd., Springfield, VA 22161 ph: (800) 553-6847 fax: $(703) 605-6900$ email: orders@ntis.fedworld.gov online ordering: http://www.ntis.gov/ordering.htm
\end{abstract}

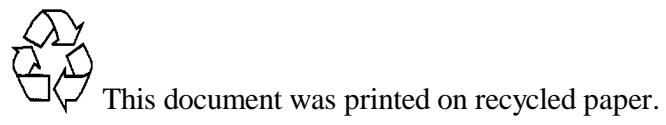




\title{
25 Year Lifetime for Flexible Buildings Integrated Photovoltaics
}

\author{
ME Gross
}

July 2010

Prepared for the U.S. Department of Energy under Contract DE-AC05-76RL01830

Pacific Northwest National Laboratory

Richland, Washington 99352 
Final Report 07-28-2010

For CRADA No. PNNL/290 between

\author{
BATTELLE \\ As operator of Pacific Northwest National Laboratory ("PNNL") \\ Under its U.S. Department of Energy Contract \\ No. DE-AC05-76RLO 1830 (hereinafter "Battelle" or "Contractor")
}

\author{
And \\ VITEX SYSTEMS, INC. \\ 25 Year Lifetime for Flexible Buildings Integrated Photovoltaics
}

\title{
OBJECTIVE
}

Although preliminary proof-of-principle of the efficacy of barrier materials and processes, first developed by Battelle at PNNL and commercialized by Vitex, has been demonstrated at the laboratory scale, there are several challenges to the practical commercial implementation of these developments in the Buildings Integrated Photovoltaics (BIPV) market. Two important issues addressed in this project are identifying a low cost substrate material that can survive in the outside environment (rain, heat, dust, hail, etc.) for 25 years and developing an encapsulation method for the photovoltaic (PV) cells that can meet the required barrier performance without driving the cost of the total barrier package out of range (remaining below $\$ 3 .{ }^{00} / \mathrm{Wp}$ ). Without these solutions, current encapsulation technologies will limit the use of PV for BIPV applications. Flexible, light-weight packaging that can withstand 25 years in the field is required for a totally flexible integrated PV package.

The benefit of this research is to make substantial progress in the development of costeffective, viable thin film barrier packaging which will be a critical enabling technology to meet the Solar America Initiative cost and device reliability goals, and to make photovoltaics (PV) more cost-competitive with electricity generated using fossil fuels. Increased PV installations will enable increased US electrical capacity and reduce dependence on imported oil through increased utilization of a widely abundant source of renewable energy (sunlight).

\section{APPROACH}

Under this CRADA project, the parties planned to focus on two areas of PV moisture barrier development. Selection of a suitable polymeric substrate capable of withstanding 25 -year outdoor exposure and the development of a barrier coating on the PV-grade substrate will be Battelle's primary contribution to this CRADA Project. The batch coating thin-film encapsulation system at Vitex has an additional technical capability for plasma-pretreatment that complements those at PNNL. To supplement the experimental plan at PNNL, Vitex planned to prepare barrier coatings on PV-grade substrates. The second priority will be the development of a vacuum lamination process with this new barrier-coated substrate material, which will be Vitex's primary contribution to this CRADA Project. Both companies have extensive experience in barrier 
development and vacuum lamination and will work closely together to solve both of these important issues facing the penetration of flexible barrier packaging into the PV market.

\section{RESULTS}

Substrate Selection: Fluoropolymer films (Teflon ${ }^{\circledR}$ family) have proven performance in PV applications and offer the best option for replacing glass in PV modules. Teflon ${ }^{\circledR}$ films have a lower refractive index and higher optical transmission than glass. This high transmittance improves the power output available from the cells. Although fluoropolymer films have the necessary optical properties to satisfy PV applications, their gas diffusion (barrier) properties are many orders of magnitude worse than those required for successful thin-film PV encapsulation. Most fluoropolymer films have water vapor permeation rates (WVTR) in the range of 1-100 $\mathrm{g} / \mathrm{m}^{2} /$ day at room temperature). For long-term survival of thin-film PV devices a substrate with a WVTR of $\sim 5 \times 10^{-4} \mathrm{~g} / \mathrm{m}^{2} / \mathrm{d}$ is required. This necessitates improvement of the barrier performance of fluoropolymer films by six to eight orders-of-magnitude while retaining optical clarity, minimal thickness and mechanical flexibility. To date multilayer thin-film coatings (developed at PNNL) are the only barrier coatings that consistently achieve these performance levels.

For this effort two Polyvinylidene Fluoride (PVDF) films were chosen for barrier development, Arkema's Kynar PVDF film and Rowland Technologies Rowlar PVDF film. We received PV grade PVDF substrate material from both companies that has the potential to meet the objectives of this CRADA for 25 year lifetime in the field and UV exposure requirements.

Monomer Chemistry: Investigation into additions to the 9085 monomer chemistry to improve polymer / oxide adhesion was the focus of this task. The 9085 monomer blend is optimized for low stress, resistance to plasma, planarizing, compatibility with OLEDs, transparency, and permeation properties; however inter-layer adhesion is not adequate. New monomer chemistry will improve the inter-layer adhesion while maintaining the good barrier and other above mentioned properties. The main components in the 9085 monomer blend were kept the same in new formulations in order to maintain good barrier and other properties. The improvement of inter-layer adhesion will be realized by addition of new adhesion promoting agents, variation of adhesion promoting agents ratio, and their weight percent in the formulation. Barrier performance with new formulations was verified by the accelerated testing of thin-film metallic calcium. Both dry and wet adhesion of new formulations will be tested by cross-hatch adhesion test per ASTM D3359.

Investigations to improve adhesion included barrier design, and plasma treatment. For barrier design, thinner polymer layers were investigated to improve adhesion. Plasma treatment of the substrate and oxide layers was also investigated to increase adhesion. Results from Vitex VEECO measurements confirmed that the most common adhesion failure is at the oxide 1 / polymer 2 interface. Tests varying plasma treatment power revealed that more power is required than traditionally used to increase adhesion, however too high of power will cause the substrate to darken, reducing light transmission. The table below outlines the barrier design, plasma treatment, and adhesion promoting agent results. 
Combination of plasma treatment and additional adhesion promoter

\begin{tabular}{|c|c|c|c|c|l|}
\hline Run\# & & Dry & \\
\hline & Dyad & $\begin{array}{c}\text { plasma } \\
\mathrm{mA}\end{array}$ & $\begin{array}{c}\text { line } \\
\text { speed }\end{array}$ & adhesion & \\
\hline 116 & 5 & $\begin{array}{c}40 \text { @ } \\
1.5 \mathrm{mpm}\end{array}$ & $7 / 10$ & 0 & $\begin{array}{l}10 \% \text { adhesion promoter } \mathrm{A} \text { and } \\
4 \% \mathrm{~B}\end{array}$ \\
\hline 117 & 5 & 30 & $7 / 10$ & 0 & $\begin{array}{l}10 \% \text { adhesion promoter } \mathrm{A} \text { and } \\
4 \% \mathrm{~B}\end{array}$ \\
\hline 118 & 5 & 30 & $7 / 10$ & 2.25 & $\begin{array}{l}20 \% \text { adhesion promoter } \mathrm{A} \text { and } \\
4 \% \mathrm{~B}\end{array}$ \\
\hline 119 & 5 & 30 & $7 / 10$ & 3.75 & $\begin{array}{l}20 \% \text { adhesion promoter } \mathrm{A} \text { and } \\
4 \% \mathrm{~B}\end{array}$ \\
\hline 120 & 5 & 12.5 & $7 / 10$ & 0 & $\begin{array}{l}20 \% \text { adhesion promoter } \mathrm{A} \text { and } \\
4 \% \mathrm{~B}\end{array}$ \\
\hline 123 & 5 & $40(30$ & $7 / 10$ & 0 & $\begin{array}{l}20 \% \text { adhesion promoter } \mathrm{A} \text { and } \\
4 \% \mathrm{~B}\end{array}$ \\
\hline 127 & 2 & 40 & $5 / 9$ & 3.9 & $\begin{array}{l}20 \% \\
4 \% \mathrm{~B}\end{array}$ \\
\hline 128 & 2 & 30 & $5 / 9$ & 5 & $\begin{array}{l}20 \% \text { adhesion promoter } \mathrm{A} \text { and } \\
4 \% \mathrm{~B}\end{array}$ \\
\hline 130 & 2 & 30 & $5 / 9$ & 5 & $\begin{array}{l}20 \% \text { adhesion promoter } \mathrm{A} \text { and } \\
4 \% \mathrm{~B}\end{array}$ \\
\hline 131 & 2 & 30 & $5 / 9$ & 5 & $\begin{array}{l}20 \% \text { adhesion promoter } \mathrm{A} \text { and } \\
4 \% \mathrm{~B}\end{array}$ \\
\hline
\end{tabular}

The interlayer adhesion of the barrier layers was improved to an acceptable level with the correct plasma treatment and adhesion promoting agents.

Barrier Process Development: In an effort to decrease barrier deposition time and develop a process that can push towards a commercial scale the oxide deposition process was changed from three passes to one. Through substrate handling improvements this once pass deposition process was successful in producing a barrier film without substrate wrinkling which makes the film unusable due to polymer layer thickness changes.

Barrier Testing: Once the multilayer coatings met required specifications for adhesion, polymer / oxide layer thickness, polymer/oxide inter-layer adhesion, and optical transmission, gas permeability was measured using the Battelle developed calcium test. The barrier samples must pass the calcium test (a rating of 4 or better) after 1000 hours testing at $85^{\circ} \mathrm{C} / 85 \% \mathrm{RH}$ which equates to a room temperature WVTR of $\sim 5 \times 10^{-6} \mathrm{~g} / \mathrm{m}^{2} / \mathrm{d}$; an order of magnitude better than the BIPV specification. The barrier samples on Kynar PVDF film do pass the calcium test at 100 hours testing at $85^{\circ} \mathrm{C} / 85 \% \mathrm{RH}$. This testing time was cut short of the 1000 goal due to the CRADA cancelation.

Vacuum Lamination: Vitex Systems has developed a vacuum lamination process for PV applications using Polyethylene terephthalate (PET) and Poly(ethylene naphthalate) (PEN) substrates that pass the IEC lifetime test requirements previous to this CRADA project. These results clearly demonstrate the proposed approach can successfully encapsulate flexible Copper 
indium gallium (di) selenide CIGS modules. Unfortunately the substrate used in these PET and PEN demonstrations yellows after long exposures to UV radiation and cannot survive the PV weatherability requirements. Therefore a similar demonstration is necessary using PVDF substrates combined with the Battelle multilayer barrier coating.

This effort was not completed due to the cancelation of the CRADA. Initial investigations into lamination adhesive and edge seal materials were conducted by Vitex Systems. This PVDF film may require an added step to keep the film tight during lamination. Possible options to keep the film tight during lamination are window screen, textured rubber, or stretcher bars based on discussions with Arkema.

\section{SUMMARY:}

Although this CRADA was cut short of completion, several key areas of investigation were either completed or nearly completed to show promise that the barrier plus Kynar PVDF film package could enable a 25 year lifetime for flexible buildings integrated photovoltaics. Initial calcium results of 100 hours testing at $85^{\circ} \mathrm{C} / 85 \% \mathrm{RH}$ indicate the barrier deposition process on PVDF films is a viable solution. Further testing and development will be required to ensure the barrier film on PVDF substrate can be successfully laminated to CIGS PV devices passing the International Electrotechnical Commission (IEC) 61646 standard of by retaining 90 percent of their original efficiency after 1000 hours testing at $85^{\circ} \mathrm{C} / 85 \% \mathrm{RH}$ and weather testing to ensure the laminated package can withstand the ultra-violet (UV) exposure for final qualification. 